\title{
Mangrove's Vegetation Structure and Composition (A Study: Manado City, North Sulawesi Province)
}

\author{
Alve Hadika $^{1}$, Mahawan Karuniasa ${ }^{2}$ \\ \{alvehadikaa@gmail.com¹,mahawancac@yahoo.com²\} \\ School of Environmental Science, Universitas Indonesia . Salemba Raya Street, \\ RW.5, Senen Districts, Daerah Khusus Ibukota Jakarta ${ }^{1,2}$
}

\begin{abstract}
This study aims to obtain results regarding the structure and composition of mangrove vegetation in the City of Manado, North Sulawesi. The research method used was descriptive and exploratory methods, while to obtain vegetation data was done by purposive sampling and plot sampling methods in each transect. Samples were taken by stratified random sampling. At the study site, no mangrove damage was found. This is thought to be caused by the role of the people of Manado City who care about the mangrove ecosystem and the research location was not located at reclamation location. In general, mangrove vegetation in Manado City was dominated by Sonneratia Alba species.. With this structure and composition data, in the next step, the government, the community or other stakeholders can monitor and maintain the condition of this ecosystem so that mangroves can grow and not be damaged.
\end{abstract}

Keywords: Conservation, Mangrove, Vegetation structure, Vegetation composition.

\section{Introduction}

Vegetation structure is a structured and stratified live stand, where the vegetation cover is obtained through the results of diameter, height, spatial distribution, diversity, and types of vegetation [7]. Fachrul added that the composition of vegetation is a list of plants found in a location or community. Mangroves are plants that live in the intertidal region (tides). This is in accordance with the statement of Irwanto [10] that mangroves are plant communities that live between sea and land and are affected by tides, currents, fresh water, and sedimentation. Mangroves are often found in estuary areas, the meeting place between river mouths and sea water.

Mangroves have different species distribution in each environmental condition where mangroves grow. Tomlinson [21] said that the distribution of mangrove vegetation in the world can be divided into 2 distribution areas, which shows the differences in the composition of mangrove vegetation from each region based on longitude. The two distribution regions include: The western region (New World Tropics), which is located at $15^{\circ}$ West $-120^{\circ}$ East, covers Western Africa, South America and the North Pacific. In total only 8 true mangrove species are found in this region. The majority of these species are concentrated in the western part of Colombia. The eastern region (Old World Tropics), located at $15^{\circ}$ East $-180^{\circ}$ East, covers Eastern Africa, India, Southeast Asia, Australia, and the Western Pacific Region. Total true mangrove species that can be found in this region number more than 40 species.Mangrove life can be influenced by two things, namely human factors and natural factors. Ministry of Forestry [5] states that human factors are the dominant 
factors causing damage to mangrove forests. Human factors also play a positive role, namely with conservation efforts. This conservation can be carried out with rehabilitation and protection of the area [7]. Conservation with rehabilitation is carried out with mangrove planting activities, while efforts to protect the area are carried out by establishing an area such as a national park, protected forest, wildlife reserve and ecotourism development area.

Efforts to protect the area in the form of a National Park in Indonesia are located in North Sulawesi Province, namely Bunaken National Park (TNB). The total area of this National Park is 89,065 ha which consists of two parts, namely the northern part of TNB (covering 5 islands namely Bunaken, Manado Tua, Mantehage, Siladen and Nain plus Tanjung Pisok around the Molas village to Tiwoho village) and the southern part of TNB (TNB) covering territorial waters from Poopoh village to Popareng village). Bunaken National Park is one of the national parks that has a wealth of natural resources, including mangrove ecosystems, seagrass ecosystems, and coral reefs, where these three ecosystems are important coastal ecosystems [16].

Manado City is one of the cities with mangrove area which is smaller than the area in other Cities / Regencies in North Sulawesi Province, namely with an area of 95,346 Ha, which is much smaller than North Minahasa Regency with an area of $4210.71 \mathrm{Ha}$ [15].

There is no damage, however by the finding of reclamation, it causes the needs of inventory in order to start the effort of conservation. Research sites include; Meras Village, Molas Village and Bohowo Village are assumed to have the largest mangrove area and different ecosystem conditions. This study was conducted to determine the structure and composition of mangrove vegetation in the city of Manado, North Sulawesi, because this conservation effort can begin with an inventory of the structure and composition of mangroves. Inventory of structure and composition can be done by analyzing ecosystem vegetation so that changes or damage to the ecosystem can be known, so that conservation efforts can proceed as they should. The results of the study can be used as a basis for policy making, monitoring changes in environmental conditions, and preservation of mangrove ecosystems.

\section{Methods}

The research material is in the form of mangrove vegetation in Manado City, covering 3 (three) villages, namely Meras Village, Molas Village, and Bohowo Village. The tools used include transect ropes, stationery, calipers, roll meters, fabric meters, plastic ziplock, GPS, litmus paper, digital cameras, and refractometers.

Sampling structure and composition of mangrove vegetation [12], namely by the method of sampling plots (method of sample sampling). Samples were taken by stratified random sampling, namely by dividing populations or samples into specific groups (strata). The determination of plot and sublot positions is carried out randomly where this has been agreed in advance.

Parameters for tree category and sampling include species, trunk diameter and tree height. Seedling categories include species, number and percentage of cover. Other parameters namely; general tree conditions and environmental conditions $(\mathrm{pH}$, salinity, and water temperature). The method used in determining the location of the purposive sampling method, where at each location carried out three repetitions. The stretched transect measures $10 \mathrm{~m} \times 10 \mathrm{~m}$ for the tree category, $5 \mathrm{~m} \times 5 \mathrm{~m}$ for the sapling or sapling category and a $1 \mathrm{~m} \times$ $1 \mathrm{~m}$ plot for seedlings or seedling [13]. Tree data with dbh (diameter at breast height) $\geq 10$ $\mathrm{cm}$, taken from each $10 \mathrm{~m} \times 10 \mathrm{~m}$ plot of the number of tree stands, tree diameter, and species 
distribution in the plot. Determination of the position of the measurement of the diameter using the recommendations of Cintron and Novelli [4], namely:

a. Branched stems below $1.3 \mathrm{~m}$ and each branch has a diameter of $\geq 10 \mathrm{~cm}$, will be measured as two separate trees,

b. Branched stems above dbh then the diameter will be measured at breast height or under the branches,

c. Stems with root forms supporting / air categories, the diameter will be measured $30 \mathrm{~cm}$ above the highest protrusion.

d. Stems that are not straight, branched or have an abnormality, the diameter measurements are taken at $30 \mathrm{~cm}$ above or below chest height.

Sampling samples are mangrove vegetation with a stem diameter of $2 \leq \mathrm{dbh}<10 \mathrm{~cm}$ and a height of $>1 \mathrm{~m}$ from a subplot of $5 \mathrm{~m} \times 5 \mathrm{~m}$ [13]. Data to be taken in the form of vegetation species and stem diameter. The data taken will be analyzed to calculate the index value, namely Density (K), Basal Area (BA), Relative Density (KR), Relative Dominance (DR), and Important Value Index (INP).

Seedling samples are mangrove vegetation with height $<1 \mathrm{~m}$ in the subplot $1 \mathrm{~m} \times 1$ $\mathrm{m}$ [13]. The data will be taken in the form of species, the number of individuals and the percentage of cover to the subplot $1 \mathrm{~m} \times 1 \mathrm{~m}$.

The analyzed vegetation data refers to Mueller-Dumbois and Ellenberg (1974), including:

\section{a. Density (K)}

Density is the number of individuals per unit in one Region / area [12]. The unit of density value is ind/ha, which is obtained using the following formula:

\section{Density $=\underline{\text { Number of ind. of a species in the whole plot }}$}

Plot Area

\section{B. Basal Area (BA)}

Basal area is the cover of mangrove forest area by a tree trunk obtained from the measurement of the diameter of the trunk. The stem diameter of each species is then converted into a basal area using the following formula:

$$
B A=\frac{\pi D^{2}}{4} \mathrm{~cm}^{2}
$$

$$
\begin{array}{ll}
\text { Information: } & \mathrm{BA}=\text { Basal Area } \\
& \pi=3.14 \\
& \mathrm{D}=\text { Diameter of trunk }
\end{array}
$$

\section{Relative Density (KR)}

Relative density is the percentage of density of each species in the transect [12]. The value of relative density is obtained using the following formula:

$$
\text { Relative Density }=\frac{\text { Species Density }}{\text { Total Density of all species }} \quad x 100 \%
$$

\section{Relative Dominance (DR)}

Relative dominance is the percentage of cover of a species to an mangrove area. The relative dominance is obtained from the basal area values for tree and sapling species, using the following formula: 


$$
D R=\frac{\text { Number of basal species }}{\text { Sample snippet area }} \times 100 \%
$$

\section{E. Importance Value Index (INP)}

Importance value is obtained to find out how much the domination of species value in a mangrove area. This importance is obtained by adding up the values of relative density and relative dominance (Curtis, 1959 in [19]).

$$
\mathrm{INP}=\mathrm{KR}+\mathrm{DR}
$$

$$
\begin{array}{lll}
\text { Information: } & \mathrm{NP} & =\text { Importance Value } \\
& \mathrm{KR} & =\text { Relative Density } \\
\mathrm{DR} & =\text { Relative Dominance }
\end{array}
$$

\section{F. Diversity Index (H')}

Diversity index is a characteristic of a community that describes the level of diversity of species of organisms contained in the community (Odum, 1993). Diversity index values refer to Shannon-Wienner (Odum, 1993), with the formula:

$$
H^{\prime}=\log N-\frac{1}{N} \sum n i \log n i
$$

$$
\begin{array}{rll}
\text { Information: } & \mathrm{H}^{\prime}= & \begin{array}{l}
\text { Shannon-Wienner } \\
\text { Diversity Index }
\end{array} \\
& \mathrm{ni} & =\begin{array}{l}
\text { Number of individuals } \\
\text { per } \mathrm{i}-\mathrm{th}
\end{array} \\
\mathrm{N} & = & \text { Total number of species }
\end{array}
$$

For values of $\mathrm{H}^{\prime}<2,303$ it means that diversity is low, values of $\mathrm{H}^{\prime} 2,303-6,908$ means moderate levels of diversity, and values of $\mathrm{H}^{\prime}>6,908$ means high levels of diversity.

\section{G. Uniformity Index ( $\left.\mathbf{J}^{\prime}\right)$}

Species Uniformity Index is a comparison between the value of diversity with Ln (natural logarithm) of the number of species [2]. The Uniformity Index formula is:

Information: $\mathrm{J}=$ Uniformity Index

$$
J^{\prime}=\frac{H^{\prime}}{\operatorname{Ln} S}
$$

$\mathrm{H}^{\prime}=$ Shannon-Wienner Diversity Index

$\mathrm{S}=$ Number of species

According to Krebs (1989), the Uniformity Index ranges from 0-1,

$\begin{array}{lll}\text { Information: } & 0.6-1 & \text { : High species uniformity } \\ & 0.4<\mathrm{J}^{1}<0.6 & \text { : Medium species uniformity } \\ & -0.4 & \text { : Low species uniformity }\end{array}$




\section{Results and discussions}

\subsection{Results}

The research location is between Longitude $124^{0} 48^{\prime} 50.87$ "E to $124^{0} 50^{\prime} 17.64$ " and Latitude $-1^{0}-33$ ' -03.33 "to- $1^{0}-31$ '-03.33". The temperature of the waters found ranged from $28^{\circ} \mathrm{C}-32^{\circ} \mathrm{C}$, salinity values varying between $30 \mathrm{ppt}-38 \mathrm{ppt}$, and the discovery of $\mathrm{pH} 7-9$. At the study site, no mangrove damage was found. This is thought to be caused by the role of the people of Manado City who care about the mangrove ecosystem and the research location was not located at reclamation location.

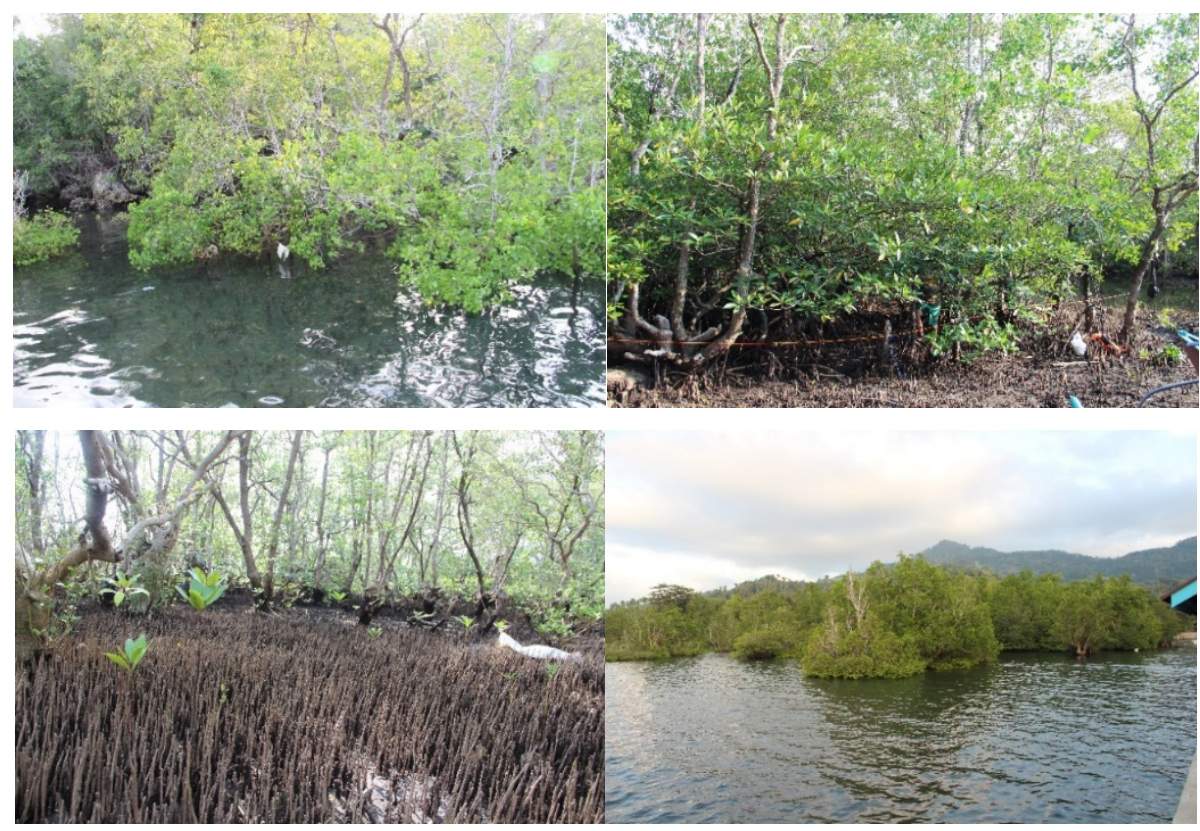

Fig. 1. Mangrove Forest of Manado City

\section{A. Composition of Mangrove Vegetation}

The result of research conducted in the city of Manado found 4 species of mangroves and 3 families of mangroves in the transec. The complete data is explained in the following table. Mangrove grouping refers to Tomlinson [21]. Mangroves that are found are major categories of mangroves. 


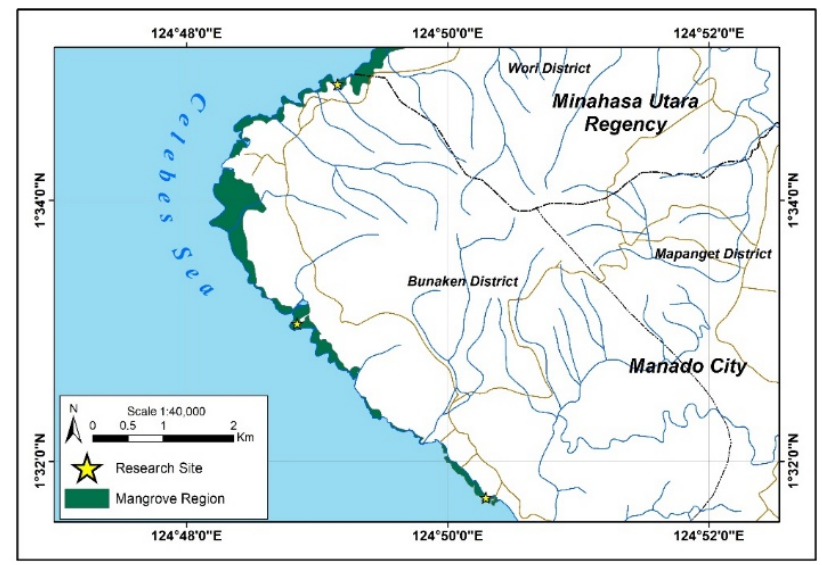

Fig. 2. Research map location

Table 1. Composition of Families and Mangrove Species Found

\begin{tabular}{llll}
\hline No & Family & Mangrove Species & Local Name \\
\hline $\mathbf{1}$ & Avicenniaceae & Avicennia . marina (Forsk.) Vierh & Api-api \\
\hline $\mathbf{2}$ & Avicenniaceae & Avicennia alba (Blume) Bakh. & Api-api \\
\hline $\mathbf{3}$ & Rhizophoraceae & Rhizophora apiculata Blume. & Posi-posi \\
\hline $\mathbf{4}$ & Rhizophoraceae & Bruguiera gymnorrhiza (L.) Lamk & - \\
\hline $\mathbf{5}$ & Sonneratiaceae & Sonneratia alba J.E. Smith & $\begin{array}{l}\text { Mange- } \\
\text { mange }\end{array}$ \\
\hline
\end{tabular}

Mangroves found in 3 locations (villages) are divided into 3 categories, namely trees, saplings, and seedlings. The tree and sapling categories were found in 3 families, while in the seedling category were found 2 families.

Table 2. Distribution of Mangrove Species by Category at Each Location

\begin{tabular}{|c|c|c|c|c|c|}
\hline No & Category & Species & Bohowo & Meras & Molas \\
\hline \multirow[t]{4}{*}{1} & Tree & Rhizophora apiculata & + & + & - \\
\hline & & Sonneratia alba & + & + & + \\
\hline & & Avicennia marina & - & + & + \\
\hline & & Avicennia alba & - & - & + \\
\hline \multirow[t]{3}{*}{2} & Sapling & Rhizophora apiculata & + & + & - \\
\hline & & Sonneratia alba & + & + & - \\
\hline & & Avicennia marina & - & + & + \\
\hline \multirow[t]{3}{*}{3} & Seedling & Bruguiera gymnorrizha & - & + & - \\
\hline & & Rhizophora apiculata & - & + & - \\
\hline & & Sonneratia alba & - & + & + \\
\hline
\end{tabular}

B. Structure of Mangrove Vegetation

Table 3. Vegetation Structure Results for Each Tree Category Species

\begin{tabular}{cccccc}
\hline $\begin{array}{c}\text { Location/Speci } \\
\text { es }\end{array}$ & $\begin{array}{c}\text { K } \\
\text { (ind/ha) }\end{array}$ & $\begin{array}{c}\text { BA } \\
\left(\mathbf{m}^{2} / \mathbf{h a}\right)\end{array}$ & $\begin{array}{c}\text { KR } \\
(\%)\end{array}$ & $\begin{array}{c}\text { DR } \\
(\%)\end{array}$ & INP (\%) \\
\hline
\end{tabular}




\begin{tabular}{|c|c|c|c|c|c|}
\hline \multicolumn{6}{|l|}{ Meras Village } \\
\hline R. apiculate & 500 & 0.13 & 36.6 & 15.9 & 52.4 \\
\hline S. alba & 433 & 0.22 & 31.7 & 26.8 & 58.5 \\
\hline A. marina & 433 & 0.47 & 31.7 & 57.3 & 89.0 \\
\hline Total & 1367 & 0.82 & 100 & 100 & 200 \\
\hline \multicolumn{6}{|l|}{$\begin{array}{l}\text { Bohowo } \\
\text { Village }\end{array}$} \\
\hline R. apiculate & 600 & 0.24 & 62.1 & 24.7 & 86.8 \\
\hline S. alba & 367 & 0.73 & 37.9 & 75.3 & 113.2 \\
\hline Total & 967 & 0.97 & 100 & 100 & 200 \\
\hline \multicolumn{6}{|l|}{ Molas Village } \\
\hline$A$, alba & 67 & 0.07 & 6.3 & 8.6 & 14.9 \\
\hline S. alba & 767 & 0.61 & 71.9 & 75.3 & 147.2 \\
\hline A. marina & 233 & 0.13 & 21.9 & 16.0 & 37.9 \\
\hline Total & 1067 & 0.81 & 100 & 100 & 200 \\
\hline
\end{tabular}

Overall the results of research on the structure of mangrove vegetation indicate that this location tends to be dominated by Sonneratia alba. This is indicated by the tendency of the high importance value index (INP) of each species in each location and its dominance in all growth categories (trees, saplings and seedlings).

The density value $(\mathrm{K})$ for the tree category obtained produced the highest density found in Meras Village, while the lowest density was located in Bohowo Village.

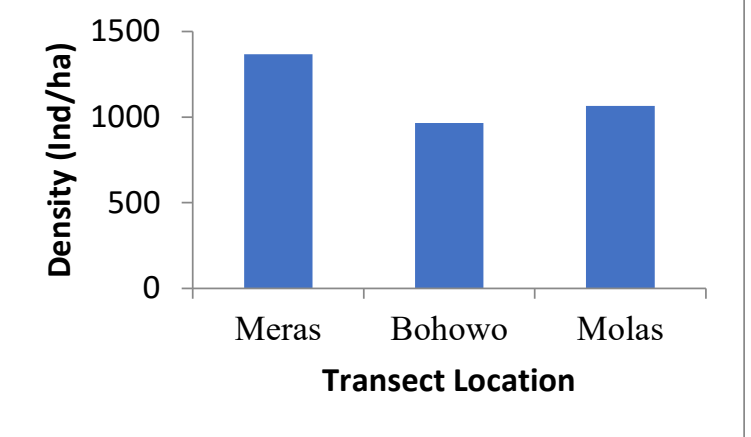

Fig. 3. Density Value of Each Tree Category Location

The research location has a Diversity Index $\left(\mathrm{H}^{\prime}\right)$ and Uniformity Index $\left(\mathrm{J}^{\prime}\right)$ which is classified as low.

Table 4. Diversity Index $\left(\mathrm{H}^{\prime}\right)$ and Uniformity Index $\left(\mathrm{J}^{\prime}\right)$ in the Tree Category

\begin{tabular}{lllll}
\hline \multicolumn{1}{c}{ Location } & H' & Category & J' & Category \\
\hline Manado City & & & & \\
\hline Meras Village & 0.48 & Low & 0.066 & Low \\
\hline Bohowo Village & 0.29 & Low & 0.042 & Low \\
\hline Molas Village & 0.32 & Low & 0.046 & Low \\
\hline
\end{tabular}


$R$. apiculata species dominated in two research locations for the sapling category, while in other villages it was dominated by the only sapling species found, namely $A$. alba species.

Table 5. Vegetation Structure Results for Each Sapling Category Species

\begin{tabular}{lccccc}
\hline Location/Species & K (ind/ha) & BA $\left(\mathbf{m}^{\mathbf{2}} \mathbf{h a )}\right.$ & KR (\%) & DR (\%) & INP (\%) \\
\hline Meras Village & & & & & \\
\hline R. apiculate & 500 & 0.04 & 71.4 & 85.1 & 156.5 \\
\hline S. alba & 33 & 0.006 & 4.8 & 12.8 & 17.5 \\
\hline A. marina & 167 & 0.001 & 23.8 & 2.1 & 25.9 \\
\hline Total & 700 & 0.047 & 100 & 100 & 200 \\
\hline Bohowo Village & & & & & \\
\hline R. apiculate & 267 & 0.03 & 88.8 & 96.8 & 185.7 \\
\hline S. alba & 33 & 0.001 & 11.2 & 3.2 & 14.3 \\
\hline Total & 300 & 0.031 & 100 & 100 & 200 \\
\hline Molas Village & & & & & \\
\hline A, alba & 233 & 0.01 & 100 & 100 & 200.0 \\
\hline Total & 233 & 0.01 & 100 & 100 & 200 \\
\hline
\end{tabular}

Having the same results as the Tree category, the Density $(\mathrm{K})$ value for the sapling category with the highest density was found in Meras Village, but the lowest density was in Molas Village.

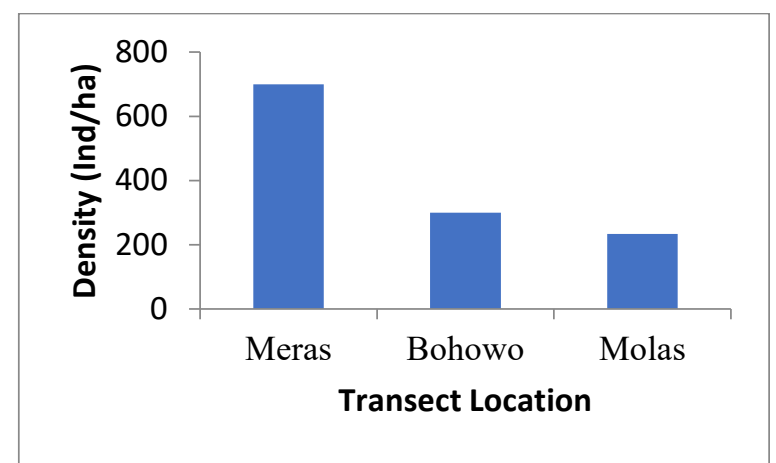

Fig. 4. Density Value of Each Location of Sapling Categories

The seedling category is dominated by S.alba. In the village of Bohowo no mangrove seedlings were found.

Table 6. Vegetation Structure Results for Each Seedling Category Species

\begin{tabular}{lcccc}
\hline \multicolumn{1}{c}{ Location/Species } & $\begin{array}{c}\text { K } \\
\text { (ind/ha) }\end{array}$ & KR (\%) & DR (\%) & INP (\%) \\
\hline Meras Village & & & & \\
\hline R. apiculate & 3333 & 20 & 25 & 45 \\
\hline S. alba & 3333 & 20 & 25 & 45 \\
\hline A. marina & 10000 & 60 & 50 & 200 \\
\hline Total & 16667 & 100 & 100 & \\
\hline Bohowo Village & & & & \\
\hline
\end{tabular}




\begin{tabular}{lcccc}
\hline Total & - & - & - & - \\
\hline Molas Village & & & & \\
\hline$A$, alba & 6667 & 100 & 100 & 200.0 \\
\hline Total & 6667 & 100 & 100 & 200 \\
\hline
\end{tabular}

The following is a comparison of the value of Density $(\mathrm{K})$ between locations:

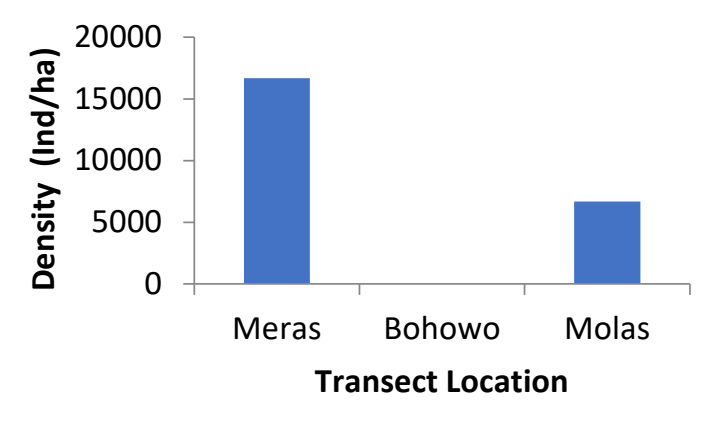

Fig. 5. Density Value of Each Location of Seedling Categories

Tree height measurements are carried out to get the height distribution in the study area. Based on the results of measurements, the distribution of mangrove height is divided into 4 (four) classes, namely $\leq 5 \mathrm{~m}, 5-10 \mathrm{~m}, 11-15 \mathrm{~m}$ and 16-20. 


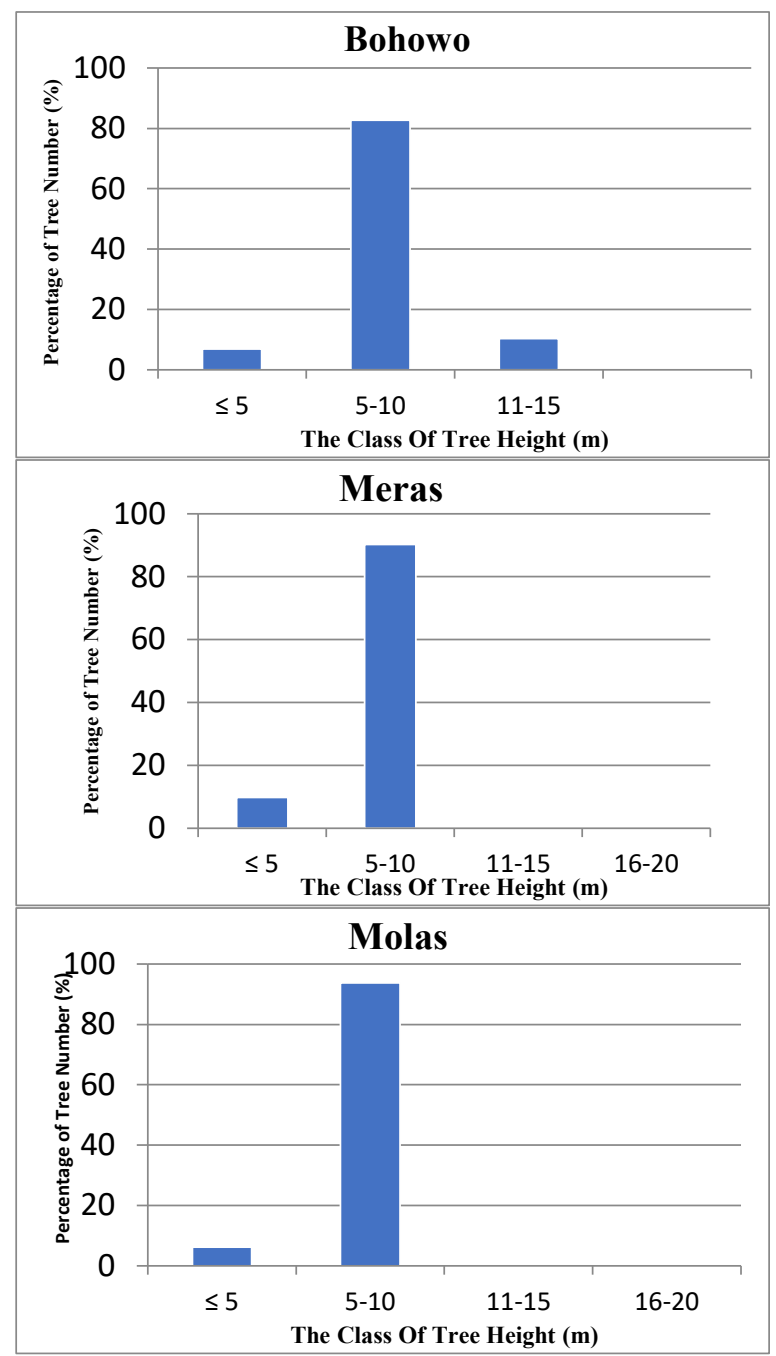

Fig. 6. Percentage of Tree Height at Each Location

\subsection{Discussion}

\section{A. Composition of Mangrove Vegetation}

The study was conducted in 3 (three) different villages that have their own uniqueness and character. The difference, for example, can be seen from the temperature, salinity, substrate and the distance between the location and community settlement. These different conditions aim to find mangrove species from various conditions where mangroves grow. The village of Bohowo has mangroves that face the sea directly and are influenced by 
tourism activities. For the location of Molas Village, this village is close to resorts and community settlements, while Meras Village is still in the form of a forest and is quite far from residential areas.

Meras village has the highest diversity and density due to the natural nature of the area at this location. This is consistent with the statement of Soegiarto and Supriyono [20] which states that human activity also contributes to the condition of mangrove ecosystems in a location. These activities such as development by opening mangrove land for ponds, illegal logging and disposal of waste into the river, either directly or not where this will damage the life of the mangrove ecosystem.In the villages of Bohowo and Molas, the low diversity and density are caused by port activities that have the potential to disrupt environmental conditions and mangrove growth so that they can indirectly damage the ecosystem and have an impact on the death of the mangroves themselves. This is in accordance with the statement of Setyawan [17] which states that mangrove ecosystems are influenced by port activities (boats and humans), large fish, and other facilities.

Overall in the study site is dominated by 4 species namely Rhizophora apiculata, Avicennia alba, Avicennia marina, and Sonneratia alba. These four species are major components and are species that can easily adapt to mud or muddy sand conditions, where the substrate conditions like this are in accordance with the conditions at the study site. This is consistent with Hardjosentono's [8] statement that dependence on substrate types is clearly demonstrated by the Avicenniaceae family, Rhizophoraceae and other major species which have a common characteristic of living on muddy or sand substrates such as shallow muddy soils, sandy beaches or corals that have layers mud or sand.

The temperature of the substrate found at the study site ranged from $28^{\circ} \mathrm{C}-32^{\circ} \mathrm{C}$, where this condition is a measure of temperature that can be tolerated by various mangrove species. It is in accordance with the statement of Percival and Womersley (1975) in [11] which states that the species Bruguiera sp., And Rhizophora sp., can live at temperatures around $28^{\circ} \mathrm{C}$, not significantly different from conditions in the field.

The $\mathrm{pH}$ factor, at the study site ranges from 7 - 9, which is also considered tolerable for the growth of productive organisms, including mangroves. Wardoyo (1975) in [9], states that waters with a $\mathrm{pH}$ of less than 4 will cause aquatic organisms to die, and $\mathrm{pH}$ above 9.5 are unproductive waters.

\section{B. Structure of Mangrove Vegetation}

The distance between locations that are still in one district, is assumed to be the reason why the species found tend to be the same. Existing environmental parameters are aspects that have an important influence on the vegetation yield found. In accordance with the statement of Arief (2003) in [14] that the type of substrate is one of the factors that influence in the regeneration process, if the substrate particles are in the form of mud, then when the fruit falls it can stick directly so that it can increase the density in the environment. If the type of sand substrate or other harder material, the fruit that falls will be difficult to stick and when the tide is carried, the fruit will be carried so that it will reduce the density in the region.

The density value of mangrove species in the tree category is 967-1367 ind / ha, with an average of 1,133 ind / ha. This result is higher when compared to the coastline Balusu District [1] which has an average density of $1027 \mathrm{ind} / \mathrm{ha}$. This is because mangroves found 
tend to be dominated by juvenile mangroves that have a large diameter of the trunk. Basal Area Measurement of the mangrove stem is obtained based on the diameter of the stem, which will produce information about the mangrove stem cover in a location. So the higher the diameter of the trunk the greater the Basal Area value and will reduce the density value of the mangrove, so that the dominant species are species that have a large tree diameter and or have a higher density than other species in a location [1].

The value of Diversity Index ( $\left.\mathrm{H}^{\prime}\right)$ and Uniformity Index $\left(\mathrm{J}^{\prime}\right)$ included in the low category with $\mathrm{H}$ 'ranging from 0.29 to 0.48 and $\mathrm{J}$ ' ranging from 0.042 to 0.066 . However, the results in Banggai Kepulauan Regency were higher than those obtained in Manado City, namely the diversity index $\left(\mathrm{H}^{\prime}\right)$ ranging from 0.48 to 2.80 and the uniformity index $\left(\mathrm{J}^{\prime}\right) 0.07$ to 0.40 . This is because the species found in Banggai Kepulauan Regency are more diverse [14].

In the seedling category, there was a decrease in the number of species, but a greater density value was obtained. Decreasing number of species and higher sapling density compared to trees, presumably because the tree category has grown and large first, thus preventing the mangrove category of tillers from getting maximum light, so mangrovecovered saplings cannot grow optimally (disrupting the process photosynthesis) which implies that mangroves remain small in size and have the potential to have high densities. This is in accordance with the opinion of Kusmana [11] that the sapling density will be higher in locations that are protected from various environmental factors that can affect the growth and development of mangrove vegetation.

Based on the results of the study, the height of mangroves in each location is dominated by classes 5-10 m. Mangroves in the city of Manado tend to fall into the category of juvenile mangroves when viewed from their height, this is based on the statement of Chapman [3] that adult mangroves have tree heights ranging from $10-30 \mathrm{~m}$ or more.

\section{Conclusion}

It can be concluded that in Manado City, North Sulawesi Province, 5 species of mangroves were found in the transect, all of which were classified as major mangrove categories. In general, mangrove tree vegetation in Manado City is dominated by Sonneratia Alba species. The value of the Diversity Index $\left(\mathrm{H}^{\prime}\right)$ and Uniformity $\left(\mathrm{J}^{\prime}\right)$ of the tree category in Manado City, is included in the low category. The height of the tree tends to be dominated by class ie $5-10 \mathrm{~m}$.

Acknowledgements. I would first like to thank my advisor, Dr. Ir. Mahawan Karuniasa MM., of the School of Enviromental Science at Universitas Indonesia. The door to. He consistently allowed this paper to be my own work, but steered me in the right the direction whenever he thought I needed it.

I would also like to thank the experts who were involved in the validation survey for this research project: Dr. Rudhi Pribadi, Fahmi Abdullah Basyari, and Irfan Cahyo Putro. Without their passionate participation and input, the validation survey could not have been successfully conducted.

Finally, I must express my very profound gratitude to my parents and to all of my friends for providing me with unfailing support and continuous encouragement throughout my years of study and through the process of researching and writing this thesis. This accomplishment would not have been possible without them. 


\section{References}

[1] Bahari A. S. 2016. 2015. Struktur dan Komposisi Vegetasi Mangrove di Balusu, Kabupaten Barru,, Provinsi Sulawesi Selatan. FPIK UNDIP. Semarang. (Undergraduate Thesis). (unpublished).

[2] Brower, J.E. dan J.H.Zar. 1977. Field and Laboratory Methods for General Ecology. W.M. Brown Company Publ. Dubuqe. Lowa.

[3] Chapman, V. J. 1976. Mangrove Vegetation. J. Cramer, Vaduz, Liechtensein, Germany.

[4] Cintron, G., dan Y. S. Novelli. 1984. Methods for studying mangrove structure. dalam editor Snedaker, S. C. dan Snedaker, J. S. The mangrove ecosystem: research methods. UNESCO, Paris, France.

[5] Departemen Kehutanan. (2001). Tentang Penyelenggaraan Hutan Kehutanan. Surat Keputusan Menteri Kehutanan Nomor Kemasyarakatan, 31/Kpts-II/2001, Dephut. Jakarta.

[6] Fachrul, M. F. 2007. Analisis Komposisi dan Struktur Vegetasi Terhadap Upaya Restorasi Kawasan Hutan Taman Nasional Gunung Gede Pangrango. Bumi Aksara. Jakarta

[7] Fikriyani, M., Mussadun. 2014. Evaluasi Program Rehabilitasi Mangrove di Pesisir Desa Bedono Kecamatan Sayung Demak. Jurnal Ruang vo. 2 No. 1.

[8] Hardjosentono. 1979. Hutan Mangrove di Indonesia dan Perannya dalam Pelestarian Sumber daya Alam. Warta Pertanian No. 3 / IX. Jakarta.

[9] Hasbi. 2004. Studi Laju Dekomposisi Serasah Mangrove Di Pantai Larea-Rea Kabupaten Sinjai. (Skripsi).UNHAS Makassar.

[10] Irwanto. (2006). Keanekaragaman Fauna pada Habitat Mangrove. Yogyakarta.

[11] Kusmana C. 2002. Pengelolaan Ekosistem Mangrove Secara Berkelanjutan dan Berbasis Masyarakat. The paper was presented in National Workshop of Mangrove Ecosystem Management. Jakarta.

[12] Mueller-Dombois, D dan H. Ellenberg. 1974. Aims and Methods of Vegetation Ecology. John Wiley, London.

[13] Pribadi, R. 1998. The Ecology of Mangrove Vegetation in Bintuny Bay, Irian Jaya Indonesia. Departement of Biological Molecular Sciences. University of Stirling, Scotland. (Ph.D. Thesis Unpublished).

[14] Rachmansyah, M. F. 2015. Struktur dan Komposisi Vegetasi Mangrove di Kabupaten Banggai dan Banggai Kepulauan. FPIK UNDIP. Semarang. (Undergraduate Thesis). (unpublished).

[15] Saputro, G.B., S. Hartini, S.Sukardjo, Al.Susanto, dan A.Poniman. 2009. Peta Mangroves Indonesia. BAKOSURTANAL. Jakarta.

[16] Schaduw, Joshian N.W. 2016. Kondisi Ekologi Mangrove Pulau Bunaken Kota Manado Provinsi Sulawesi Utara. Jurnal LPPM Bidang Sains dan Teknologi

[17] Setyawan, Ahmad Dwi., K, Winarno., Indrowuryatno., Wiryanto., dan A, Susilowati. 2004. Tumbuhan Mangrove di Pesisir Jawa Tengah: 3. Diagram Profil Vegetasi. Jurusan Biologi FMIPA, Universitas Sebelas Maret (UNS) Surakarta.

[18] Smith, T. J. 1992. Forest Structure. In: Tropical mangrove ecosystem. Robertson, A. I. and D. M. Alongi (Eds), American Geophysical Union, Washington.

[19] Soerianegara, I dan A. Indrawan 1982. Ekologi Hutan Indonesia. Departemen Manajemen Hutan Fakultas Kehutanan Institusi Pertanian Bogor, Bogor.

[20] Sugiarto dan Supriyono. 1996. Penghijauan Pantai. Penebar Swadaya. Jakarta.

[21] Tomlinson, P.B. 1994. The Botany of Mangroves. Cambridge University Press. New York 